\title{
Physical Condition of an Animal, Using as an Example the Common Eider, Somateria mollissima
}

\author{
ARnAUd J. CABANAC \\ Département de Biologie, Université du Québec à Rimouski, 300 allée des Ursulines, Rimouski, Québec G5L 3A1 Canada \\ Present address : Parc Aquarium du Québec, 1675 avenue des Hôtels, Sainte-Foy, Québec G1W 4S3 Canada \\ Cabanac, Arnaud J. 2003. Physical condition of an animal, using as an example the Common Eider, Somateria mollissima. \\ Canadian Field-Naturalist 117(2): 230-235. \\ An index of the physical condition of an animal should describe its endogenous available energy. The welfare of the animal \\ depends on its ability to spend its stored energy (lipid and protein) in order to survive the environmental and behavioural \\ challenge at the particular time of its capture. I propose a new index to predict the survival chance of the subject. The new \\ index of physical condition takes into account the available endogenous energy reserves and the known needs of the species \\ at that particular time of year. I further illustrate this new method of estimating the physical condition by running a trial with \\ Common Eiders, Somateria mollissima.
}

Key Words: Behaviour, ecology, physiology, management, fitness.

An index of physical condition of an animal is usually obtained by integrating the energy reserve of the organism under consideration and its ability to spend this energy (Evans and Smith 1975; Ringelman and Szymczak 1985; Blem 1990). In the wild, fasting is known to happen routinely, either voluntarily, for example in birds as a reproductive strategy to protect the nest, or involuntarily because of food shortage (e.g., Mrosovsky and Sherry 1980; Drent and Daan 1980; Blem 1990; Wingfield et al. 1997). Knowing whether some individuals, or an entire population, are in good physical condition is therefore a difficult task but it is more than often a basic question for ecologists and ethologists.

\section{Physiology}

The energy reserve is usually evaluated through analysis of the subject's body composition. Originally, fat was considered as the animal's only energy reserve (e.g., Odum et al. 1964; Pond 1978; Griminger 1986), but recent literature on body composition in birds underlined that muscle tissues are also a labile energy store (e.g., Evans and Smith 1975; McLandress and Raveling 1981; Cherel et al. 1988; Lindström and Piersma 1993; Choinière and Gauthier 1995). Further, it is also known that the body can better tolerate lipid than protein depletion. The lipid reserves can go close to total depletion (e.g., Gorman and Milne 1971; Milne 1976; Korschgen 1977; Pond 1978; Groscolas 1986; Robin et al. 1988; Parker and Holm 1990; Boismenu et al. 1992) whereas more than $30-50 \%$ decrease of protein content leads mammals and birds to death (e.g., Montemurro and Stevenson 1960; Garrow et al. 1965; Gorman and Milne 1971; Peret and Jacquot 1972; Parker and Holm 1990; Boismenu et al. 1992). This implies that lipids have to be stored in the adipose tissue in order to delay protein breakdown and its lethal diminution to anticipate and counter food shortage. In seals, the proteins sustained only $4-8 \%$ of the metabolism during $52 \mathrm{~d}$ of fasting (Nordøy et al. 1990). The corresponding figures in geese and penguins, were $6 \%$ over $40 \mathrm{~d}$ (Le Maho et al. 1981), and $4 \%$ over $90 \mathrm{~d}$ of fasting (Robin et al. 1988). This is certainly the main reason for the high survival of these animals in extreme conditions. The knowledge of lowered but yet present protein breakdown was lacking in 1969 when obese humans underwent long-term fasting as treatment for obesity, and deaths occurred even though the patients still had huge fat stores at the time of their deaths (Barnard et al. 1969). This example casts light on the fact that both lipid and protein contents are important energy reserves that must both be taken under consideration to estimate the subject's welfare.

Several studies on fasting birds have shown that, in penguins (e.g., Le Maho et al. 1976; Cherel and Le Maho 1985; Robin et al. 1988) and in geese (e.g., Le Maho et al. 1981; Cherel et al. 1988; Boismenu et al. 1992), the loss in weight due to food shortage follows three different rates of decrease when graphically plotted against time. The above references are summarized in Table 1, which gives the time course of weight loss in three periods. Period I would last only a few days and the rate of weight loss in this first period is relatively high. It corresponds to the use of the glycogen stores and is associated with a drop in protein utilization. Period II is marked by the use of fat as the main metabolic fuel, with a slower decrease in body weight over time. This second period could last several weeks. Period III would last several days during which amino acids fulfill the energy requirements. This third and last period is marked by an increase in protein breakdown and a sharp increase in the subject's weight loss. The three periods of Table 1, which are proposed from bird data, apply as well to fasting mammals; e.g., humans 
TABLE 1. Summary in three periods of time for weight loss during fasting.

\begin{tabular}{cccc}
\hline \hline Period & Duration & Physiology & Source of energy \\
\hline I & 1-2 days & fast weight loss (decreasing rate) & glycogen \& protein \\
fat \\
II
\end{tabular}

(Cahill 1976) and seals (Nordøy et al. 1990). It appears clearly therefore that, to have a realistic estimate of the survival chance of an organism, one should distinguish fat from lean mass in body composition analysis (see also Blem 1990; Van der Meer and Piersma 1994). [The integrated response to fasting is only partially understood and is beyond the scope of the present work; for more on the subject of body weight stability see Mrosovsky 1990; Belkhou et al. 1990; Cabanac et al. 1999.]

Thus, by definition, the index of physical condition should indicate on the subject's ability to spend its energy (Ringelman and Szymczak 1985) or, as stated by Evans and Smith (1975), on its chance of survival at a particular time of year. This is so, because the score of an animal having low reserves of energy may not represent the same physical condition in spring as in fall. The variables chosen to represent energy demand are usually size-related measures, such as body masses, with or without association of some structural measurements (e.g., Odum et al. 1964; Child 1969; Evans and Smith 1975; Ringelman and Szymczak 1985; Johnson et al. 1985; Moser and Rusch 1988; also Blem 1990; Piersma and Davidson 1991; Chastel et al. 1995). However, little attention has been paid to the different amounts of energy loss that could be tolerated in the subject's various periods of life.

In the following I propose a physical condition index (PCI) that takes into account not only the available body reserves but also the time of year. The index is based on how much protein and lipid an organism could maximally lose in the particular periods of its life. This index describes and predicts the subject's welfare. I chose to test estimating the ability of the bird to survive from the size of its energy reserve, on the Common Eider because the biology of that large duck is well documented, but a similar exercise could equally well have used a mammal.

\section{Natural History of the Common Eider Unstable body weight}

In Common Eiders, Somateria mollissima, females feed very little or not at all from laying to hatching (Gorman and Milne 1971; Cantin et al. 1974; Milne 1976; Korschgen 1977; Parker and Holm 1990). In such long-term spontaneous fasting, the metabolism of the bird is fueled solely by endogenous energy reserves. Consequently, such behaviour is reflected in massive weight loss by the ducks. During the 22-26 days of the incubation period, a female loses $22-42 \%$ of its weight (29.5\%, Korschgen 1977; 35.2\%, Kuresoo and Paakspuu 1983; 22.3\%, Parker and Holm 1990; $35.6 \%$, Gabrielsen et al. 1991; 41.6\%, Bolduc and Guillemette 2003). Further, Parker and Holm (1990) reported that the breeding females also fasted for about 6-7 additional days before incubating and that such eiders would have used already about $34 \%$ of their stored energy at that time. Previous reports mentioned a $20-21 \%$ increase in body weight of females that will breed in the next summer (Milne 1976; Korschgen 1977; Parker and Holm 1990). This gain in weight was designated as "the storage of nutrients and energy necessary for egg production", as it corresponds to about the weight that will be lost by the females during the following laying period (Korschgen 1977; Parker and Holm 1990). Therefore, in total, a female eider would lose $44-54 \%$ of its weight during 28-33 d of the laying and incubating periods (Cantin et al. 1974; Milne 1976; Korschgen 1977; Parker and Holm 1990; Gabrielsen et al. 1991), 19\% of which would be the clutch weight (Parker and Holm 1990). This impressive weight loss of a breeding female eider is similar to the $39-44 \%$ weight loss reported in geese after 34-40 d of fasting (Le Maho et al. 1981; Boismenu et al. 1992) and to the $52 \%$ and $68 \%$ of weight loss of Emperor Penguin, Aptenodytes forsteri, and King Penguin chicks after a four-month and a five-month fasting period (Robin et al. 1988; Cherel and Le Maho 1985).

Fasting may also happen involuntarily in the wild because of food shortage. In condition of extreme food shortage a fasting eider may totally deplete its metabolic reserves. Wårnes (1988) reported that some starving eiders lost $35-39 \%$ of their weight during the winter 1982. Also, Kervella and M. Guillemette (unpublished observation) measured a $21.3-24.8 \%$ weight loss in starving eiders (males and females) from the Gulf of St. Lawrence in winter 1999. These eiders were exposed accidentally to oil-polluted water along the coast of the Gulf of St Lawrence in March 1999 and were apparently unable to feed (see also Hartung 1967; Gorman and Milne 1971).

Interestingly, in these two examples of fasting eiders, the populations starving in winter lost about the same weight (21.3-24.8\% and 35-39\%) before dying as what the female is capable of losing during the incubation period (22-42\%), and much less than these females if the laying period is taken into account (Parker and Holm 1990). It makes sense that a heavier female (because of its increased weight in anticipation of the 
breeding period seen above), can lose more weight than a thinner one that did not accumulate such reserves. However, this suggests different types of body weight loss, thus allowing survival during the reproduction season.

\section{Energy reserve}

Several studies have shown that eiders, like other birds and mammals, use both fat and protein reserves as endogenous sources of energy (Milne 1976; Korschgen 1977; Parker and Holm 1990). Further, Milne (1976) measured the gross variation in body weight, protein, and lipid content during the natural fast of the breeding period. We can also discriminate in eiders, in Milne's (1976) figure 1, the above-defined Periods I, II, and III on fasting geese and penguins. Milne (1976: figure 1) indicated that from mid-April to mid-June, the protein content diminished only weakly, but the fat content decreased sharply, resulting in a drop of body weight. As seen above, these changes mimic the definition of Period II. A sharp decrease of the eiders' protein content starts between mid-June and early July and lasts until the end of incubation. This later period would correspond to Period III. Period I is reportedly difficult to identify and probably would occur in the first days of laying. Our interpretation of Milne's (1976) results certainly deserves additional work. However, the results of Gabrielsen et al. (1991) may be similarly viewed: they concluded that fat was the major fuel during incubating fasting eiders, which would tend to confirm my hypothesis of a similar physiology in the utilization of energy reserve in fasting eiders, as that well-known for geese and penguins. Also, Parker and Holm (1990) measured only a smaller rate of protein loss during the incubation period $(1.9 \mathrm{~g} /$ day) than that measured during the few days of the laying period (16.8 g/day).

\section{Index of physical condition of the eider}

It follows from the above considerations that an index of body condition should integrate the bird's body weight, which can fluctuate over time, but also its lipid and protein contents, to provide an accurate estimate of the available energy reserves at the moment of its capture. Further, we saw above that the interpretation of protein and fat reserves, in terms of the bird's welfare, would not be the same if the duck were sampled in winter, vs. during the breeding period. Thus, for the following, I collected available data from the literature on body weight and lipid and protein contents in wintering and breeding eiders, to estimate the energy reserve for a typical eider sampled in these periods. It must be hypothesized therefore that profound physiological changes take place during the year, allowing longer fasting without deleterious results during the reproductive season. This leads me to propose an index with different parameters for these two periods in the bird's year. Two reports were available:
Cabanac and Guillemette (unpublished observation) correlated lipid and protein contents with body mass on 127 wintering eiders, and obtained the following equations:

Lipid $=0.165$ (body weight) $-168.7 \quad$ (Equation 1)

Protein $=0.142$ (body weight) +49.4 (Equation 2$)$

There were no differences between males and females.

Korschgen (1977) correlated the same variables for females during the incubating period and reported the following equations:

Lipid $=0.420$ (body weight) $-444.4 \quad($ Equation 3$)$

Protein $=0.160$ (body weight) +48.0 (Equation 4)

\section{Exhaustion threshold}

Starving or near-starving-to-death eiders (males and females) were studied by Gorman and Milne (1971); their lipid content was lowered down by $95 \%$ over a winter. In the breeding period, several studies reported similar results in females, which became totally depleted of fat by hatching; yet these females recovered thereafter (Milne 1976; Korschgen 1977; Parker and Holm 1990). Thus, if we remove fat from equations 1 \& 3 (lipid equal to zero) it follows that body weight of these fat-depleted eiders would theoretically correspond to $1022 \mathrm{~g}$ in winter (derived from Equation 1: body weight $=168.7 / 0.165)$, and to $1058 \mathrm{~g}$ during the incubation period (derived from Equation 3: body weight $=444.4 / 0.420)$. As seen above in the physiology of fasting, eiders of lightest body weights in both periods would get their energy from protein breakdown, and would be in Period III of the fasting metabolism (short period of increased catabolism of proteins for neoglucogenesis). However, a female eider is known to raise its protein content before laying (Milne 1976; Parker and Holm 1990), and this slight boost in protein content may explain some of the small discrepancy of body weight of fat-depleted eiders in winter and in the breeding period.

Spontaneously fasting females of the breeding period were shown to endure protein depletion up to $37 \%$ (Parker and Holm 1990), and even 50\% (Gorman and Milne 1971). Moreover, Korschgen (1977) reported some eiders at the beginning of the laying period to weigh $2530 \mathrm{~g}$, which when incorporated into Equation 4 suggested $453 \mathrm{~g}$ was protein (Protein $=0.160(2530)$ +48.0 ). Equation 3 predicts that in the breeding period a fat-depleted eider would weigh $1058 \mathrm{~g}$, which when incorporated into Equation 4 suggested $217 \mathrm{~g}$ was protein $($ Protein $=0.160(1058)+48.0)$. This suggests that the protein content in a fat-depleted eider would correspond to a $52 \%$ reduction. Considering that an eider depleted of lipid would be in its critical Period III, it is likely that such protein depletion would be close to the maximal endurance of protein breakdown. Thus, at the end of incubation, Gorman and Milne's (1971) results with $50 \%$ of protein depletion would indicate that some females might approach their physiological limit at the time of hatching, as is known to occur. 
On the other hand, during the winter, starving, or near-to-death starving, eiders (males and females) were reported to have their protein content diminished only by about $23 \%$ at the moment of their death (Gorman and Milne 1971). The discrepancy of protein utilization of wintering eiders and breeding eiders suggests that a female in the breeding period could endure more protein breakdown than during the winter. However, the wintering eiders of Gorman and Milne's (1971) study were oil-contaminated, and a possibly lethal contamination by petroleum may have acted on the birds' endurance of protein depletion (possibly lowering it). In a study on the body composition of some 131 wintering eiders of the Gulf of St. Lawrence, we obtained (Cabanac and Guillemette, unpublished observations) an average body weight of $1815 \mathrm{~g}$ for both females and males, of which $307 \mathrm{~g}$ protein (Equation 2). With Equation 1 I can predict that in the winter period a fatdepleted eider would weigh $1022 \mathrm{~g}$, of which $195 \mathrm{~g}$ is protein (Equation 2). This suggests that the protein content in a fat-depleted eider would correspond to about a $37 \%$ reduction. Again, considering that an eider depleted of lipid would be in its critical Period III, I believe that such protein depletion would be close to the maximal endurance of protein breakdown of wintering eiders.

\section{Physical Condition Index (PCI)}

The Index of Physical Condition (PCI) corresponds to the endogenous reserves content in lipid and protein correlated to the body weight at that time (winter and breeding period), minus the maximal rate of utilization of protein and lipid. The maximal utilization of endogenous energy was shown to be $95 \%$ of the lipid, both in winter and during the breeding period; the maximal utilization of protein in those periods was $37 \%$ and $52 \%$, respectively, corresponding to fat-depleted eiders. From these data I may now propose the following indexes describing physical condition during the two different periods (where $\mathrm{F}$ and $\mathrm{P}$ are fat and protein mass expressed in $\mathrm{g}$ ):

Wintering $\quad \mathrm{PCI}=0.05 * \mathrm{~F}+0.63 * \mathrm{P} \quad$ (Equation 5) Breeding $\quad \mathrm{PCI}=0.05 * \mathrm{~F}+0.48 * \mathrm{P} \quad$ (Equation 6)
The equation is the same in both periods, but the parameters change for wintering and breeding eiders. Because these equations use the minimal energy contents, the index describes the lowest physical condition that an average eider could sustain in each period. If an individual scored below those critical levels, its survival should be compromised.

\section{Examples}

Data from the literature on body composition of several Common Eiders, permits a check on the validity of this new PCI. The results are indicated in Table 2 and the mean results are illustrated in Figure 1:

Common Eiders in the pre-laying period are, as we have seen above, supposedly in good physical condition, and their mean ( \pm s.d.) PCI was:

PCI $=245.1 \pm 5.45$

The PCI of eiders at the end of the voluntary fasting period, a time of poor physiological conditions, was:

PCI $=125.4 \pm 10.00$

Thus, these results seem to support the validity of the new PCI. Moreover, an eider in the laying period should have already burnt some valuable amount of energy (as seen above) but would still have to run the entire incubating period. Accordingly, its intermediary value for PCI (PCI $=187.0 \pm 17.41)$ was similar to that of the eiders in the pre-laying and the hatching periods as shown in Figure 1.

The physical condition index can be applied to groups of eiders of unknown welfare to find out their probability of survival. Of course, the calculation implies the sacrifice of some individuals, but the results will inform the researcher on the state of the population. The index is easy to obtain; it needs only the body weight (and carcass analysis if the subject is measured out of the periods of validity of our PCI) of the individual to be evaluated, and the period of the year corresponding to its capture. Similar reasoning could be applied to individuals at the winter period. PCI in winter corresponded to 200.0 (Table 2). For example in winter 1999, a small ecological catastrophe (oil slick) happened at Havre-Saint-Pierre: Some eiders were unable to feed and also suffered hypothermia due to damaged plumage; over 1000 eiders died (Kervella and

TABLE 2. Physical condition index (PCI) of some Common Eiders, as obtained from the body weight of the ducks and from Equations 3, 4, and 6 for Pre-laying, Pre-incubating, and Hatching periods, and from Equations 1, 2, and 5 for Wintering eiders.

\begin{tabular}{|c|c|c|c|c|}
\hline $\begin{array}{c}\text { PRE-LAYING } \\
\text { PCI (bodyweight, g) }\end{array}$ & $\begin{array}{c}\text { PRE-INCUBATING } \\
\text { PCI (body weight, g) }\end{array}$ & $\begin{array}{c}\text { HATCHING } \\
\text { PCI (body weight, g) }\end{array}$ & $\begin{array}{c}\text { WINTERING } \\
\text { PCI (body weight, g) }\end{array}$ & SOURCE \\
\hline $245.3(2500)$ & & $113.3(1150)$ & & Milne 1976 \\
\hline & $179.9 \quad(1830)$ & $121.2 \quad(1232)$ & & Korschgen 1977 \\
\hline $250.5 \quad(2553)$ & 174.2 (1773) & $133.8 \quad(1368)$ & & Parker and Holm 1990 \\
\hline $239.6 \quad(2442)$ & 206.8 (2106) & $133.5 \quad(1357)$ & & Gabrielsen et al. 1991 \\
\hline & & & $200.0(1817)$ & $\begin{array}{l}\text { Cabanac and Guillemette, } \\
\text { unpublished }\end{array}$ \\
\hline $245.1 \pm 5.45$ & $187.0 \pm 17.41$ & $125.4 \pm 10.00$ & 200.0 & Mean PCI ( \pm s.d.) \\
\hline
\end{tabular}




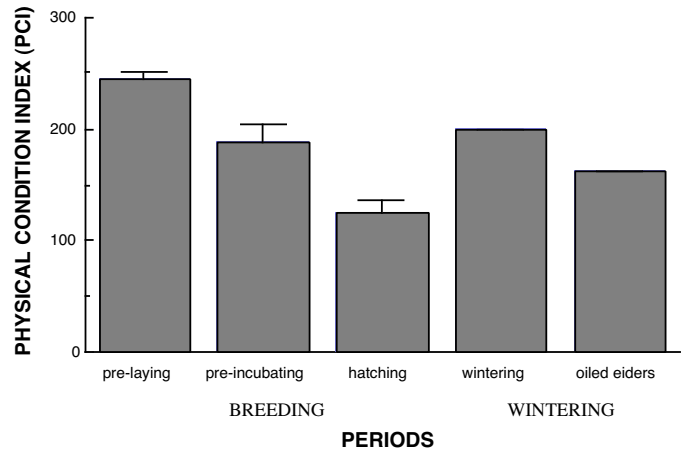

FIGURE 1. Physical condition index (PCI) for breeding (prelaying, laying, and incubating) and wintering Common Eiders. PCI withdraw the energy required by the subject at that particular time of year from the endogenous reserves (lipid and protein). In breeding eiders, PCI is illustrated for the pre-laying, the laying, and the incubating periods; in winter, healthy ducks and oiled eiders are represented.

Guillemette, unpublished observation): at autopsy the males weighed $1469 \mathrm{~g}$ and the females $1397 \mathrm{~g}$ (mean $1433 \mathrm{~g}$ ), which with Equations 1, 2, and 5, corresponds to $\mathrm{PCI}=162.7$. Interestingly this figure is much lower than the PCI computed for the wintering eiders (Table 2, Figure 1); this would indicate that these eiders were in bad physical condition.

\section{Wildlife Management}

I have shown that a physical condition index is easy to obtain. An accurate estimation of the energy reserve (lipid and protein) of the organism under consideration is necessary, together with an integration of its ability to survive. The PCI provides an estimate of the subject's chance of survival at a particular time of the year obtained by withdrawing the energy required by the animal at that particular time of year from the endogenous reserves. I have shown that such a method works at least for Common Eiders, but I believe that a similar protocol could be applied to other wildlife and would facilitate their management.

\section{Acknowledgment}

The research was supported by a CRSNG-NSERC Government of Canada postdoctoral fellowship.

\section{Literature Cited}

Barnard, D. L., J. Ford, E. S. Garnett, R. J. Mardell, and A. E. Whyman. 1969. Changes in body composition produced by prolonged total starvation and refeeding. Metabolism 18: 564-569.

Belkhou, R., J.-P. Robin, Y. Cherel, and Y. Le Maho. 1990. Utilization of lipid versus protein reserves during longterm fasting in mammals and birds. Pages 231-241 in Animal nutrition and transport process. Edited by Mellinger, Basel, and Karger. Comparative Physiology 5.
Blem, C. 1990. Avian energy storage. Current Ornithology 7: 59-113.

Boismenu, C., G. Gauthier, and J. Larochelle. 1992. Physiology of prolonged fasting in Greater Snow Geese (Chen caerulescens atlantica). Auk 109: 511-521.

Bolduc, F., and M. Guillemette. 2003. Incubation constancy and mass loss in the Common Eider (Somateria mollissima). Ibis 145: 329-332.

Cabanac, M., C. Michel, and C. Gosselin. 1999. Corticotropin Releasing Hormone and body weight regulation: the behavioral approach. Nutritional Neuroscience 2: 385-401.

Cahill, G. F. 1976. Starvation in man. Journal of Clinical Endocrinology and Metabolism 5: 397-415.

Cantin, M., J. Bédard, and H. Milne. 1974. The food and feeding of common eiders in the St. Lawrence estuary in summer. Canadian Journal of Zoology 52: 319-334.

Chastel, O., H. Weimerskirch, and P. Jouventin. 1995. Body condition and seabird reproductive performance: a study of three petrel species. Ecology 76: 2240-2246.

Cherel, Y., and Y. Le Maho. 1985. Five months of fasting in king penguin chicks: body mass loss and fuel metabolism. American Journal of Physiology 249: R387-R392.

Cherel, Y., J.-P. Robin, and Y. Le Maho. 1988. Physiology and biochemistry of long-term fasting in birds. Canadian Journal of Zoology 66: 159-166.

Child, G. I. 1969. A study of nonfat weights in migrating Swainson's Thrushes (Hylocichla ustulata). Auk 86: 327338.

Choinière, L., and G. Gauthier. 1995. Energetics of reproduction in female and male greater snow geese. Oecologia 103: 379-389.

Drent, R. H., and S. Daan. 1980. The prudent parent: energetic adjustments in avian breeding. Ardea 68: 225-252.

Evans, P. R., and P. C. Smith. 1975. Studies on shorebirds at Lindisfare, Northumberland. II. Fat and pectoral muscle as indicators of body condition in the Bar-tailed Godwit. Wildfowl 26: 64-76.

Gabrielsen, G. W., F. Mehlum, H. E. Karlsen, Ø. Andersen, and H. Parker. 1991. Energy cost during incubation and thermoregulation in the female Common Eider Somateria mollissima. Norsk Polarinstitutt Skrifter 195: 51-62.

Garrow, J. S., K. Fletcher, and D. Halliday. 1965. Body composition in severe infantile malnutrition. Journal of Clinical Investigation 44: 417-425.

Gorman, M., and H. Milne. 1971. Seasonal changes in the adrenal steroid tissue of the Common Eider Somateria mollissima and its relation to organic metabolism in normal and oil-polluted birds. Ibis 113: 218-228.

Griminger, P. 1986. Lipid metabolism. Pages 345-358 in Avian physiology. Edited by P. D. Sturkie. Springler-Verlag, New York.

Groscolas, R. 1986. Changes in body mass, body temperature and plasma fuel levels during the natural breeding fast in male and female emperor penguins Aptenodytes forsteri. Journal of Comparative Physiolology-B 156: 521-527.

Hartung, R. 1967. Energy metabolism in oil covered ducks. Journal of Wildlife Management 31: 798-804.

Johnson, D. H., G. L. Krapu, K. L. Reinecke, and D. G. Jorde. 1985. An evaluation of condition indices for birds. Journal of Wildlife Management 49: 569-575.

Korschgen, C. E. 1977. Breeding stress of female eiders in Maine. Journal Wildlife Management 41: 360-373.

Kuresoo, A., and V. Paakspuu. 1983. Physiological starvation and its adaptative role in the breeding-cycle of diving 
ducks. Communication of the Baltic Commission for the Study of Bird Migration 15: 83-92.

Le Maho, Y., P. Delclitte, and J. Chatonnet. 1976. Thermoregulation in fasting emperor penguins under natural conditions. American Journal of Physiology 231: 913-922.

Le Maho, Y., H. V. Van Kha, H. Koubi, G. Dewasmes, J. Girard, P. Ferré, and M. Cagnard. 1981. Body composition, energy expenditure, and plasma metabolites in long-term fasting geese. American Journal of Physiology 241 (Endocrinology and Metabolism 5): E342-E354.

Lindström, A., and T. Piersma. 1993. Mass changes in migrating birds: the evidence for fat and protein storage re-examined. Ibis 135: 70-78.

McLandress, M. R., and D. G. Raveling. 1981. Changes in diet and body composition of Canada Geese before spring migration. Auk 98: 65-79.

Milne, H. 1976. Body weights and carcass composition of the Common Eider. Wildfowl 27: 115-122.

Montemurro, D. G., and J. A. F. Stevenson. 1960. Survival and body composition of normal and hypothalmic obese rats in acute starvation. American Journal of Physiology 198: 757-761.

Moser, T. J., and D. H. Rusch. 1988. Indices of structural size and condition of Canada Geese. Journal Wildlife Management 54: 202-208.

Mrosovsky, N. 1990. Rheostasis, The physiology of change. Oxford: Oxford University Press. 183 pages.

Mrosovsky, N., and D. F. Sherry. 1980. Animal anorexias. Science 207: 837-842.

Nordøy, E. S., O. C. Ingebretsen, and A. S. Blix. 1990. Depressed metabolism and low protein catabolism in fasting grey seal pups. Acta Physiologica Scandinavica 139: 361369.

Odum, E. P., D. T. Rogers, and D. L. Hicks. 1964. Homeostasis of the nonfat components of migrating birds. Science 143: $1037-1039$.
Parker, H., and H. Holm. 1990. Patterns of nutrient and energy expenditure in female Common Eiders nesting in Svalbard. Auk 107: 660-668.

Peret, J., and R. Jacquot. 1972. Nitrogen excretion on complete fasting and on a nitrogen-free diet-endogenous nitrogen. Pages 73-118 in International encyclopedia of food and nutrition. Protein and amino acid functions. Volume II. Edited by E. J. Bigwood, Pergamon Press, Oxford.

Piersma, T., and N. C. Davidson. 1991. Commentaries: Confusions of mass and size. Auk 108: 441-444.

Pond, C. M. 1978. Morphological aspects and the ecological and mechanical consequences of fat deposition in wild vertebrates. Annual Reviews Ecological System. 9: 519-570.

Ringelman, J. K., and M. R. Szymczak. 1985. A Physiological condition index for wintering mallards. Journal of Wildlife Management 49: 564-568.

Robin, J-P., M. Frain, C. Sardet, R. Groscolas, and Y. Le Maho. 1988. Protein and lipid utilization during long-term fasting in emperor penguins. American Journal of Physiology 254: R61-R68.

Van der Meer, J., and T. Piersma. 1994. Physiologically inspired regression models for estimating and predicting nutrient stores and their composition in birds. Physiological Zoology 67: 305-329.

Wårnes, E. 1988. Massedød av aerfugl på Sørlandet vinteren 1981/82. Vår Fuglefauna 11: 71-74.

Wingfield, J. C., K. Hunt, C. Breuner, K. Dunlap, G. S. Fowler, L. Freed, and J. Lepson. 1997. Environmental stress, field endocrinology, and conservation biology. Pages 95-131 in Behavioral approaches to conservation in the wild. Edited by Clemmons and Buchholz Cambridge University Press, Cambridge, U.K.

Received 3 December 2001

Accepted 15 September 2003 